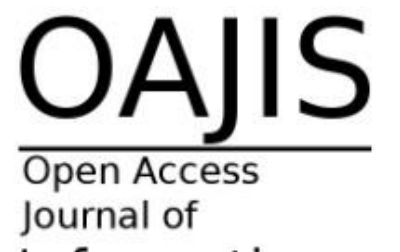

Information

Systems

is.its.ac.id/pubs/oajis/
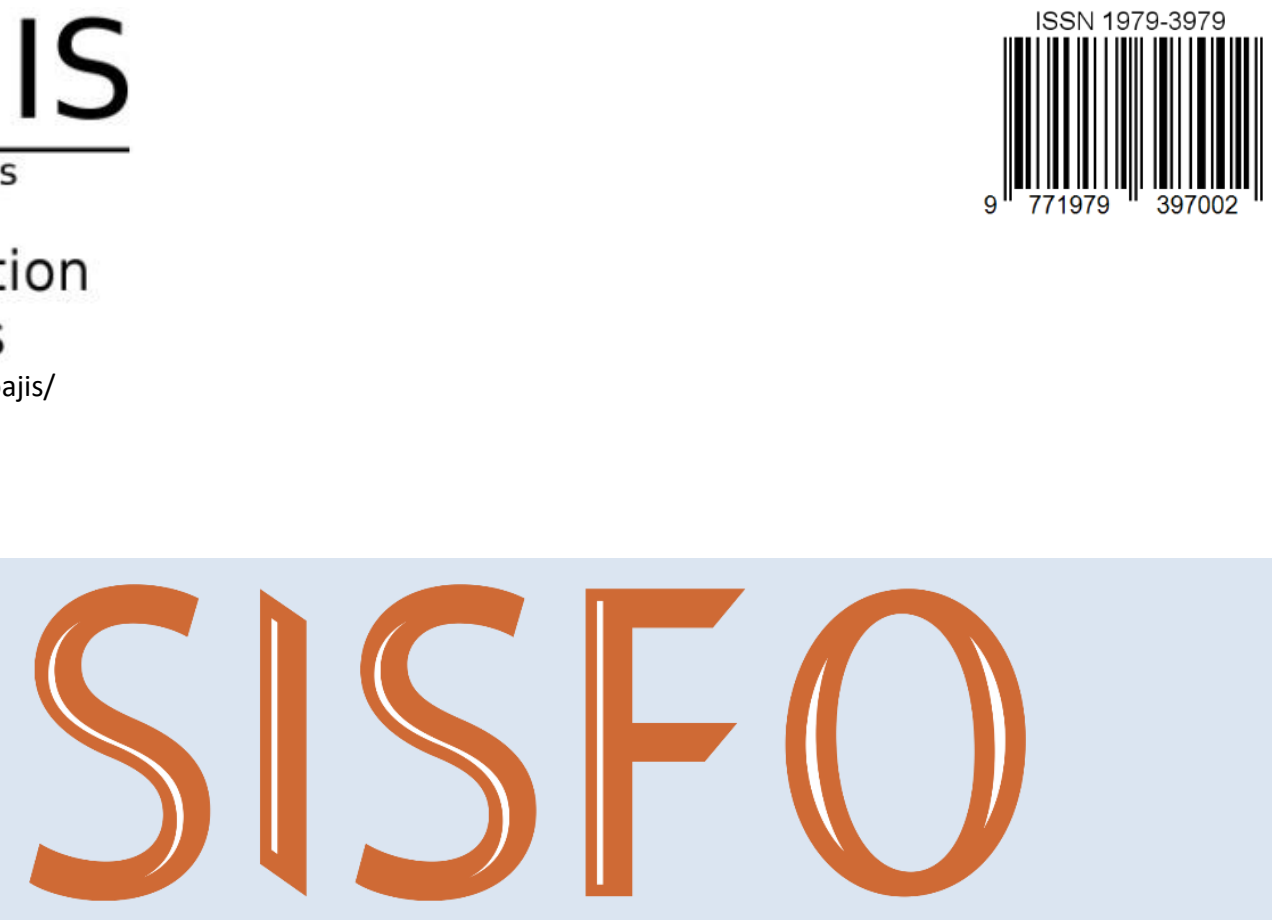

Inspirasi Profesional Sistem Informasi

\section{People}

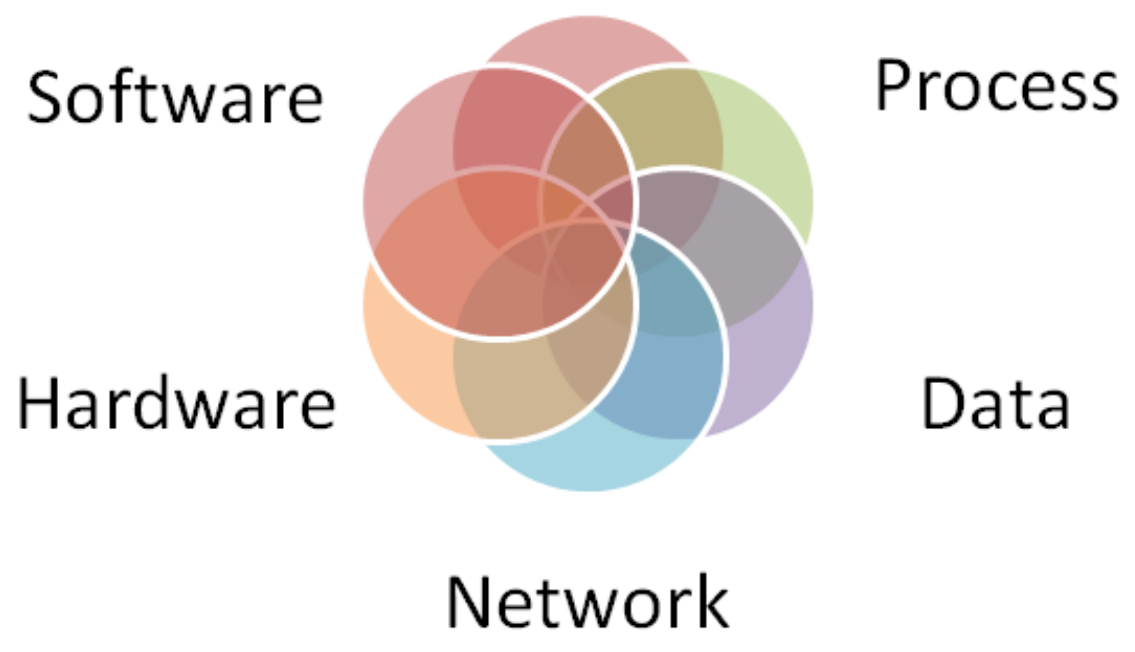


OAJIS

Journal of

Information

Systems

is.its.ac.id/pubs/oajis/

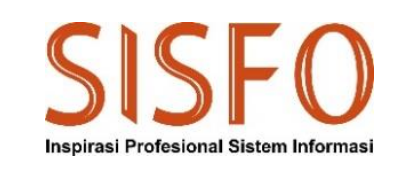

Jurnal Sisfo Vol. 08 No. 02 (2019) i-ii

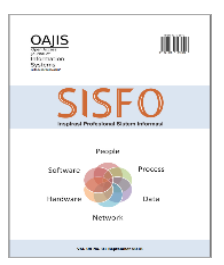

\section{Pimpinan Redaksi}

Faizal Mahananto

\section{Dewan Redaksi}

Eko Wahyu Tyas Darmaningrat

Amna Shifia Nisafani

Arif Wibisono

Rully Agus Hendrawan

\section{Tata Pelaksana Usaha}

\section{Achmad Syaiful Susanto}

Rini Ekowati

\section{Sekretariat}

Departemen Sistem Informasi - Fakultas Teknologi Informasi dan Komunikasi

Institut Teknologi Sepuluh Nopember (ITS) - Surabaya

Telp. 031-5999944 Fax. 031-5964965

Email: editor@jurnalsisfo.org

Website: http://jurnalsisfo.org

Jurnal SISFO juga dipublikasikan di Open Access Journal of Information Systems (OAJIS)

Website: http://is.its.ac.id/pubs/oajis/index.php 
OAJIS

Journal of

Information

Systems

is.its.ac.id/pubs/oajis/

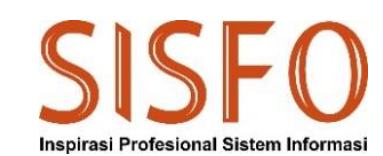

Jurnal Sisfo Vol. 08 No. 02 (2019) i-ii

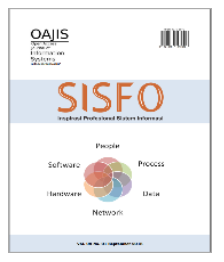

\section{Mitra Bestari}

Satria Fadil Persada, S.Kom., M.BA., Ph.D. (Institut Teknologi Sepuluh Nopember)

Sholiq, S.T., M.Kom., M.SA. (Institut Teknologi Sepuluh Nopember)

Nur Aini Rakhmawati, Ph.D. (Institut Teknologi Sepuluh Nopember)

Retno Aulia Vinarti, Ph.D. (Institut Teknologi Sepuluh Nopember)

Leon Andretti Abdillah, S.Kom., M.M. (Universitas Bina Darma)

Radityo Prasetianto W, S.Kom., M.Kom. (Institut Teknologi Sepuluh Nopember) 
OAJIS Journal of

Information

Systems

is.its.ac.id/pubs/oajis/

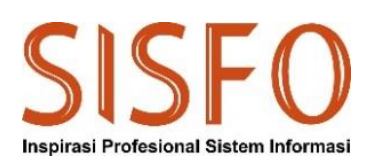

Jurnal Sisfo Vol. 08 No. 02 (2019) iii

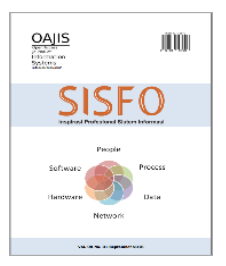

\section{Daftar Isi}

Evaluasi Kerangka Kerja Perencanaan Keberlangsungan Bisnis pada PT. Lotte Chemical Titan Nusantara

Mochammad Ikmal Amirullah, Apol Pribadi Subriadi......

ShopVis: Visualisasi Interaktif Persebaran Toko Daring di Indonesia Menggunakan Crowdsourced Data

Ruktin Handayani, Mohammad Arif Rasyidi. 99

Blended Learning dari Perspektif Para Guru Sekolah di Pondok Pesantren

Ahmad Muklason, Faizal Mahananto, Wiwik Anggraeni, Arif Djunaidy, Edwin Riksakomara .....

Pembuatan Prosedur dan Formulir Service Desk Pemerintahan Kota Madiun Berdasarkan ITIL V3

Zulaikah Effendi, Anisah Herdiyanti, Tony Dwi Susanto.

Rancang Bangun Dashboard dan Visualisasi Data Kickstarter dengan Pendekatan Business Intelligence

Irmasari Hafidz, Achmad Mirfak, Anisah Azhari, Aufar Ilham Adianto, Berry Humaidi Fuad, M. Ihsan Farabi .... 
Halaman ini sengaja dikosongkan 


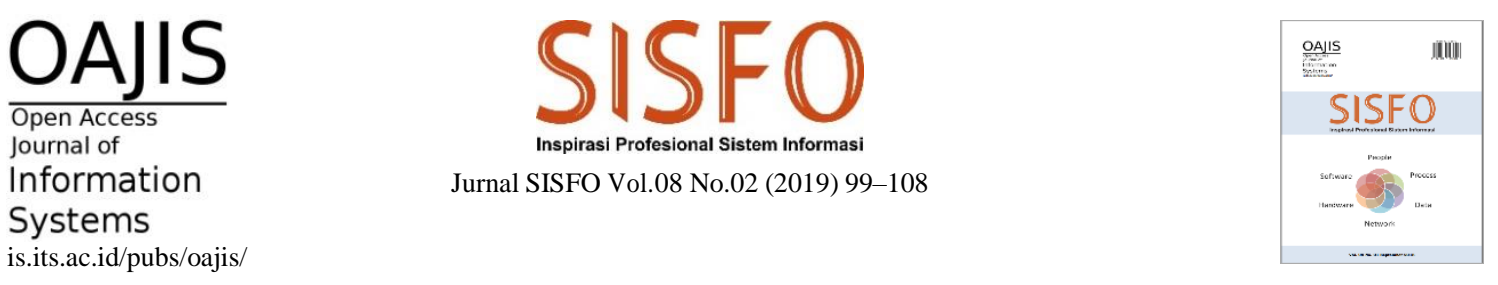

\title{
ShopVis: Visualisasi Interaktif Persebaran Toko Daring di Indonesia Menggunakan Crowdsourced Data
}

\author{
Ruktin Handayani*, Mohammad Arif Rasyidi \\ Departemen Informatika, Universitas Internasional Semen Indonesia
}

\begin{abstract}
The current statistics on electronic-commerce distribution in Indonesia mostly only reveal the number and value of transactions, but not the distribution, both in terms of the quantity of online stores and the types of goods sold. This study aims to develop a visualization of the distribution of online stores in Indonesia. The data used in this study is crowdsourced data taken from one of online marketplaces in Indonesia. The data is analyzed and processed to produce statistics on the distribution of online stores by region and type of goods. These statistics are displayed in map visualization for ease of use. This visualization can be utilized by the government or stakeholders to monitor the development of online stores in each region and make strategic decisions. The visualization can be used further to obtain statistics and the distribution of the types of goods sold online, comparing them to ordinary trade and typical products from each region. Underdeveloped regions can then be motivated to develop their electronic commerce to their full potential. This research is also expected to be used as a reference for even distribution of electronic commerce in Indonesia.
\end{abstract}

Keywords: Crowdsourced Data, Online Marketplaces, Map Visualization, Electronic Commerce

\begin{abstract}
Abstrak
Statistik distribusi perdagangan elektronik di Indonesia saat ini sebagian besar hanya menunjukkan persebaran jumlah dan nilai transaksi, namun tidak menunjukkan persebaran jumlah toko daring, jenis barang dan nilai transaksinya. Penelitian ini bertujuan untuk mengembangkan visualisasi peta persebaran toko daring yang ada di Indonesia. Data yang digunakan dalam penelitian ini adalah hasil dari crowdsourced data yang bersumber dari toko daring di Indonesia. Data dianalisis dan diproses untuk menghasilkan statistik tentang distribusi toko daring berdasarkan wilayah dan jenis barang. Statistik ini ditampilkan dalam bentuk visualisasi peta untuk kemudahan penggunaan. Dengan adanya visualisasi tersebut, pemerintah atau pemegang kepentingan akan dapat memantau perkembangan toko daring di masing-masing wilayah. Daerah yang memiliki potensi namun belum berkembang secara maksimal dapat didorong untuk mengembangkan perdagangan elektroniknya. Visualisasi tersebut dapat digunakan lebih lanjut untuk mendapatkan statistik maupun persebaran jenis-jenis barang yang dijual secara daring, membandingkannya dengan perdagangan biasa serta produk khas dari masing-masing wilayah. Diharapkan hasil penelitian ini dapat dijadikan dasar untuk pemerataan perkembangan perdagangan elektronik di Indonesia.
\end{abstract}

Kata kunci: Visualisasi, Toko Daring, Crowdsourced Data, Perdagangan Elektronik

() 2019 Jurnal SISFO.

Histori Artikel: Disubmit 25-01-2019; Direvisi 30-01-2019; Diterima 31-01-2019; Tersedia online 31-01-2019

\footnotetext{
* Corresponding Author

Email address: ruktin.handayani@uisi.ac.id (Ruktin Handayani)

https://doi.org/10.24089/j.sisfo.2019.01.002
} 


\section{Pendahuluan}

Perkembangan teknologi informasi dan komunikasi (TIK) yang pesat dalam dekade terakhir turut berperan dalam berkembangnya sektor perdagangan elektronik (e-commerce) di Indonesia. Berdasarkan data Kementrian Komunikasi dan Informatika (Kominfo) Indonesia [1], jumlah pengguna internet di Indonesia pada tahun 2015 sebanyak 93,4 juta jiwa dimana 77\%-nya menggunakan internet untuk mencari informasi produk dan berbelanja secara daring. Pada tahun yang sama, jumlah belanja daring di Indonesia mencapai 7,4 juta orang dengan nilai USD 3,56 milyar. Angka ini diperkirakan akan naik secara signifikan pada tahun 2016 sehingga mencapai 8,7 juta orang dan total nilai belanja sebesar USD 4,89 milyar. Dengan masih rendahnya persentase pengguna internet yang melakukan belanja daring serta didukung semakin meratanya pembangunan infrastruktur TIK dan banyaknya jumlah penduduk, sektor perdagangan elektronik di Indonesia memiliki potensi yang sangat besar untuk dikembangkan. Untuk mengetahui potensi tersebut diperlukan statistik persebaran toko daring di Indonesia agar dapat menentukan potensi setiap daerah. Statistik yang ada saat ini hanya menunjukkan persebaran jumlah dan nilai transaksi, namun tidak menunjukkan persebaran jumlah toko daring, jenis barang dan nilai transaksinya

Penelitian ini bertujuan untuk mengembangkan visualisasi peta persebaran toko daring yang ada di Indonesia. Dengan adanya visualisasi tersebut, pemerintah atau pemegang kepentingan akan dapat memantau perkembangan toko daring di masing-masing wilayah. Daerah yang memiliki potensi namun belum berkembang secara maksimal dapat didorong untuk mengembangkan perdagangan elektroniknya. Visualisasi tersebut dapat digunakan lebih lanjut untuk mendapatkan statistik maupun persebaran jenisjenis barang yang dijual secara daring, membandingkannya dengan perdagangan biasa serta produk khas dari masing-masing wilayah. Diharapkan hasil penelitian ini dapat dijadikan dasar untuk pemerataan perkembangan perdagangan elektronik di Indonesia.

Metode yang gunakan dalam penelitian ini adalah ekstraksi data web (web scraping) untuk mengambil data dari pasar daring (marketplace) yang ada di Indonesia. Hal ini dilakukan karena tidak ada data publik yang siap untuk digunakan. Metode ini banyak digunakan sebagai komponen dari pengindeksan web, integrasi data antar website, data mining, dan aplikasi-aplikasi lain seperti deteksi perubahan dan perbandingan harga produk daring.

Beberapa permasalahan yang dihadapi dalam proses ekstraksi data ini antara lain:

1) Tidak semua pasar daring mencantumkan lokasi toko. Sehingga untuk mendapatkan peta persebaran toko daring di Indonesia, hanya beberapa pasar daring yang dapat digunakan sebagai sumber data. Permasalahan ini dapat diatasi dengan memilih pasar daring yang menyediakan lokasi toko pada lamannya. Beberapa pasar daring yang memenuhi kriteria tersebut antara lain adalah Tokopedia [2] dan Bukalapak [3].

2) Karena data pasar daring merupakan crowdsourced data yang bersumber dari pengguna (toko daring), maka beberapa data mungkin tidak akurat. Toko dapat mencantumkan harga produk yang jauh lebih rendah daripada yang sebenarnya untuk menarik minat pelanggan. Permasalahan ini diduga dapat diatasi dengan menggunakan berbagai metode deteksi outlier, seperti Tukey's Test [4], Chauvenet's criterion [5], dan Dixon's Q test [6].

3) Resource yang dibutuhkan cukup besar, mengingat banyaknya data yang tersedia. Hal ini selain menjadi beban bagi peneliti, juga membebani server pasar daring, terutama jika data dengan volume besar diakses dalam waktu yang singkat.

4) Tidak semua data dapat diambil. Beberapa pasar daring membatasi banyak data yang dapat diakses. Dengan demikian, tidak bisa didapatkan statistik yang 100\% akurat.

Untuk mengatasi permasalahan ketiga dan keempat di atas maka digunakan metode random sampling. Pada random sampling, beberapa data yang diambil sepenuhnya secara acak digunakan untuk mendapatkan statistik yang mewakili keseluruhan data yang ada [7]. 


\section{Tinjauan Pustaka/Penelitian Sebelumnya}

\subsection{Visualisasi Data}

Visualisasi data merupakan salah satu bagian dari sains data yang bertujuan untuk mengkomunikasikan informasi secara jelas dan efisien menggunakan grafik, plot, dan infografis. Visualisasi data yang baik, tidak hanya dapat mengkomunikasikan informasi dengan lebih baik, namun juga akan membantu untuk memahami data secara lebih jelas dan mendalam [8]. Untuk menyampaikan gagasan secara efektif, bentuk visual dan fungsional harus seimbang, memberikan pengetahuan yang mendalam mengenai data yang kompleks dengan mengkomunikasikan aspek-aspek utamanya dengan cara yang lebih intuitif [9]. Beberapa contoh diagram yang dapat digunakan untuk visualisasi data antara lain: diagram batang, histogram, scatter plot, diagram jaring, streamgraph, treemap, gantt chart, dan heat map.

Dalam tahun-tahun terakhir, visualisasi telah menjadi salah satu bidang penelitian yang aktif dan vital karena perannya dalam membantu manusia dalam memahami dan menganalisis data yang semakin meningkat baik dari segi volume maupun availabilitasnya. Visualisasi telah banyak diterapkan dalam berbagai macam bidang yang dapat dikelompokkan menjadi empat kategori [10], visualisasi graf misalnya di bidang sosial media [11], teks [12], peta (data spasial) seperti demografi [13], dan data multivariat [14]. Di bidang perdagangan elektronik sendiri, visualisasi telah banyak dimanfaatkan, di antaranya untuk keperluan data mining [15]. Hanya saja masih belum ada penelitian yang fokus dalam memvisualisasikan persebaran toko daring. Dengan demikian, terdapat celah penelitian yang dapat diambil disini. Visualisasi yang digunakan dalam penelitian ini berupa visualisasi peta karena melibatkan data-data wilayah yang ada di Indonesia sehingga untuk memudahkan pengguna dalam mengakses wilayah tersebut secara langsung melalui peta.

\subsection{Deteksi Outlier}

Beberapa metode untuk mendeteksi outlier antara lain sebagai berikut.

1) Tukey's Test [4]

Outlier dideteksi dengan menggunakan interquartile range. Jika Q1 dan Q3 melambangkan kuartil 1 dan 3, maka outlier adalah data dengan nilai diluar range $\left[Q_{1}-1.5\left(Q_{3}-Q_{1}\right), Q_{3}+1.5\left(Q_{3}-Q_{1}\right)\right]$.

2) Chauvenet's Criterion [5]

Jika $\bar{x}$ dan $s$ melambangkan rata-rata dan standar deviasi sampel, maka sebuah nilai $x_{i}$ dianggap outlier jika $T=\left|x_{i}-\bar{x}\right| / s$ lebih besar dari nilai yang ada pada tabel nilai kriteria Chauvenet.

3) Dixon's Q Test [6]

Data diurutkan secara naik: $x_{1}, x_{2}, \ldots, x_{n}$. Nilai $Q$ dihitung sebagai rasio perbedaan dari nilai yang dicurigai sebagai outlier dan nilai terdekatnya dengan range $\left[\frac{x_{i}-x_{i-1}}{x_{n}-x_{1}}\right]$ kemudian hasilnya dibandingkan dengan tabel nilai kritis $Q$.

\section{Metodologi}

Tahapan yang penelitian sebagaimana ditunjukkan pada Gambar 1 antara lain sebagai berikut. 


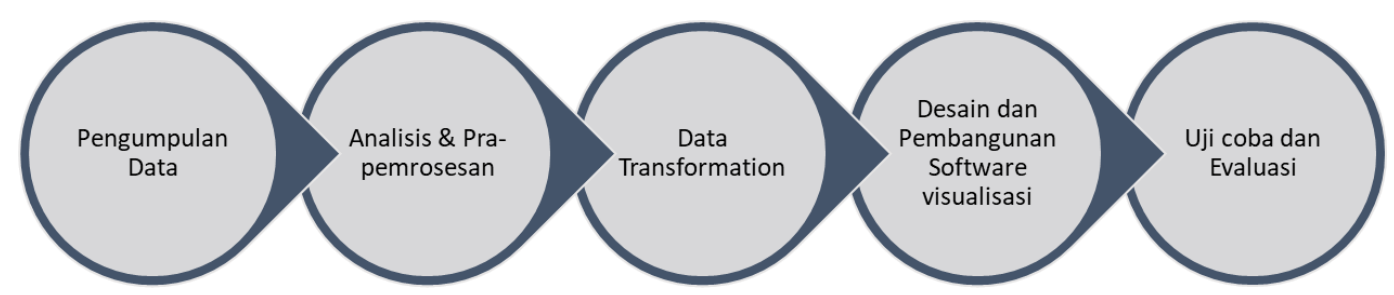

Gambar 1. Metode penelitian

\subsection{Spesifikasi}

Data yang digunakan dalam penelitian ini didapatkan dari salah satu pasar elektronik yang ada di Indonesia. Data ini mencakup informasi dasar dari 1,019,493 toko daring yang tersebar dalam 34 provinsi dan 460 kota serta kabupaten yang ada di seluruh Indonesia pada bulan April 2018. Selain itu, digunakan juga 20,699,536 data dasar produk yang dijual oleh toko-toko tersebut. Produk-produk tersebut dapat dikelompokkan lebih lanjut ke dalam 1,462 kategori. Data tersebut selanjutnya disimpan dalam database untuk kemudian diproses lebih lanjut. Skema dari database ini ditunjukkan pada Gambar 2.

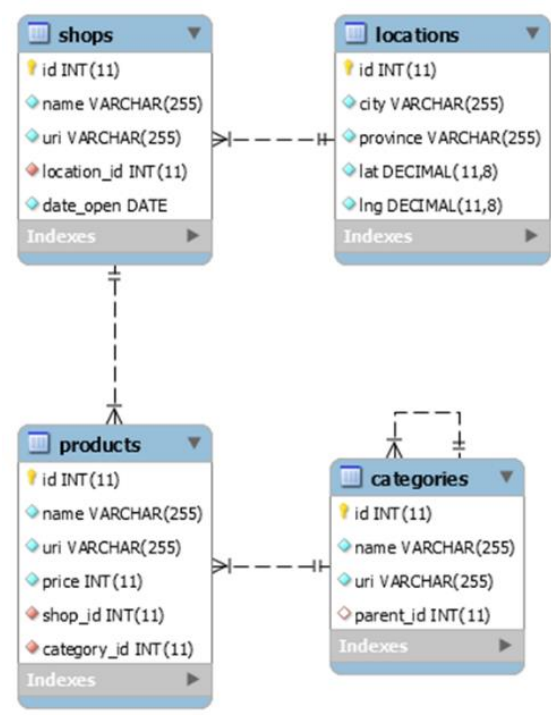

Gambar 2. Skema database awal

\subsection{Analisis dan Pra-Pemrosesan Data}

Pada tahap ini, dilakukan pembersihan untuk data yang telah diperoleh sebelumnya. Pembersihan data dilakukan untuk menghilangkan data-data yang bersifat outlier. Karena data pasar daring merupakan crowdsourced data yang bersumber dari pengguna (toko daring), maka beberapa data mungkin tidak akurat. Toko dapat mencantumkan harga produk yang jauh lebih rendah daripada yang sebenarnya untuk menarik minat pelanggan. Beberapa metode yang dapat digunakan dalam mendeteksi data outlier ini antara lain adalah Tukey's Test [4], Chauvenet's criterion [5], dan Dixon's Q test [6]. Pada penelitian ini, Tukey's Test digunakan untuk mengidentifikasi dan menghilangkan data produk dengan harga di luar batas wajar pada masing-masing kategori. Pada Tukey's Test, outlier dideteksi dengan menggunakan interquartile range (IQR). Jika $\mathrm{Q}_{1}$ dan $\mathrm{Q}_{3}$ melambangkan kuartil 1 dan 3, maka outlier adalah data dengan nilai diluar range $\left[Q_{1}-1.5\left(Q_{3}-Q_{1}\right), Q_{3}+1.5\left(Q_{3}-Q_{1}\right)\right]$. Prosedur penerapan Tukey's test pada proses pembersihan data ini ditunjukkan pada pseudocode di Gambar 3 berikut. 


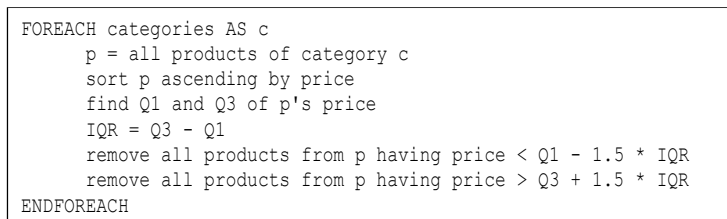

Gambar 3. Prosedur penerapan Tukey's test pada proses pembersihan data

\subsection{Transformasi Data (Data Transformation)}

Data yang telah dibersihkan pada langkah sebelumnya selanjutnya diubah ke dalam format yang mudah untuk dapat digunakan dalam tahapan selanjutnya sebagaimana ditunjukkan pada Gambar 4.

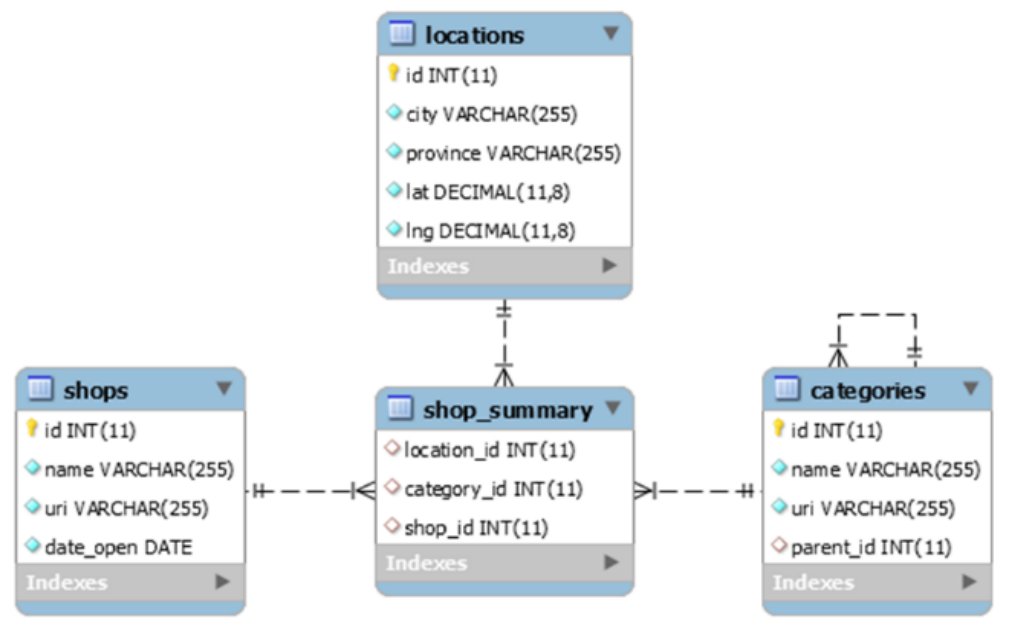

Gambar 4. Skema database setelah transformasi

Dari skema ini terlihat bahwa sebuah toko daring dapat memiliki beberapa kategori berbeda. Namun, dalam visualisasinya, jumlah toko pada masing-masing kategori dihitung secara distinct berdasarkan IDnya. Misal, toko $t_{1}$ menjual barang dengan kategori $c_{2}$ dan $c_{3}$, toko $t_{2}$ menjual barang dengan kategori $c_{2}$, dan $c_{2} \& c_{3}$ merupakan subkategori dari $c_{1}$, maka dalam visualisasinya, jumlah toko dengan kategori $c_{1}$ adalah 2 seperti diilustrasikan pada Gambar 5 berikut.

\begin{tabular}{|cc|}
\hline Toko & Kategori \\
\hline $\mathrm{t} 1$ & $\mathrm{c} 2$ \\
\hline $\mathrm{t} 1$ & $\mathrm{c3}$ \\
\hline $\mathrm{t} 2$ & $\mathrm{c} 2$ \\
\hline
\end{tabular}

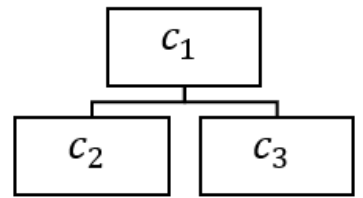

\begin{tabular}{|cc|}
\hline Kategori & Jumlah Toko \\
\hline c1 & 2 \\
\hline c2 & 2 \\
\hline c3 & 1 \\
\hline
\end{tabular}

Gambar 5. Ilustrasi cara perhitungan jumlah toko dalam kategori

\subsection{Desain dan Pembangunan Software Visualisasi}

Perancangan visualisasi dilakukan untuk memilih antarmuka yang dapat mengkomunikasikan informasi dengan lebih efektif. Setelah perancangan dilakukan, software dibangun mengacu pada rancangan yang telah dibuat sebelumnya. Software visualisasi yang dikembangkan berbasis web dan dilakukan dengan 
menggunakan Apache sebagai web servernya, PHP sebagai bahasa pemrograman, dan MySQL untuk databasenya.

\subsection{Uji Coba dan Evaluasi}

Visualisasi yang telah dibuat selanjutnya akan dievaluasi dari segi fungsi serta performanya. Performa software visualisasi akan diukur menggunakan waktu akses yang terdiri atas tiga kategori, yaitu document (base HTML), assets (CSS, javascript), dan data yang divisualisasikan (JSON).

\section{Hasil dan Pembahasan}

\subsection{Data}

Tabel 1 adalah data yang sudah dikumpulkan melalui proses crowdsourced data yang bersumber dari pengguna (toko daring) di Indonesia.

\begin{tabular}{lll} 
& Tabel & 1. Tabel data komponen toko daring di Indonesia \\
\hline No & \multicolumn{1}{c}{ Data } & \multicolumn{1}{c}{ Jumlah } \\
\hline 1 & Kota & 460 \\
2 & Kategori & 1.462 \\
3 & Toko Daring & 1.019 .493 \\
4 & Produk & 20.699 .536 \\
\hline
\end{tabular}

Gambar 6 adalah data yang dihasilkan dari proses pembersihan untuk menghilangkan data-data yang bersifat outlier (data yang tidak akurat). Setelah dikurangi dengan toko yang "non aktif" maka data yang dihasilkan lebih efektif dibanding data sebelumnya yaitu: (1) Produk sebanyak 20,363,623 dan (2) toko sebanyak 544,107.

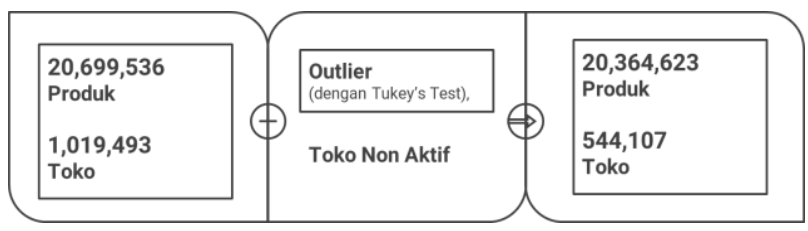

Gambar 6. Hasil deteksi outlier

\subsection{Hasil Visualisasi Peta Persebaran Toko Daring di Indonesia}

Penelitian ini menghasilkan sebuah visualisasi persebaran toko daring di Indonesia berbasis website dan selanjutnya disebut ShopVis. Persebaran toko daring dapat dilihat dengan mudah melalui bentuk peta persebaran yang dihasilkan dalam penelitian ini. Persebaran dan jumlah toko daring dapat dilihat di setiap propinsi dengan cara menyentuh masing-masing propinsi di peta, sebagaimana tampak pada Gambar 7 .

Gambar 8 menyajikan statistik persebaran toko daring berdasarkan daerah dan kategori toko. Hal ini dapat digunakan lebih lanjut untuk membandingkan jenis perdagangan biasa dan perdagangan secara elektronik, mengetahui produk khas dari masing-masing wilayah sehingga dapat dijadikan dasar untuk pengambilan keputusan dan pemerataan perkembangan perdagangan elektronik di Indonesia. 


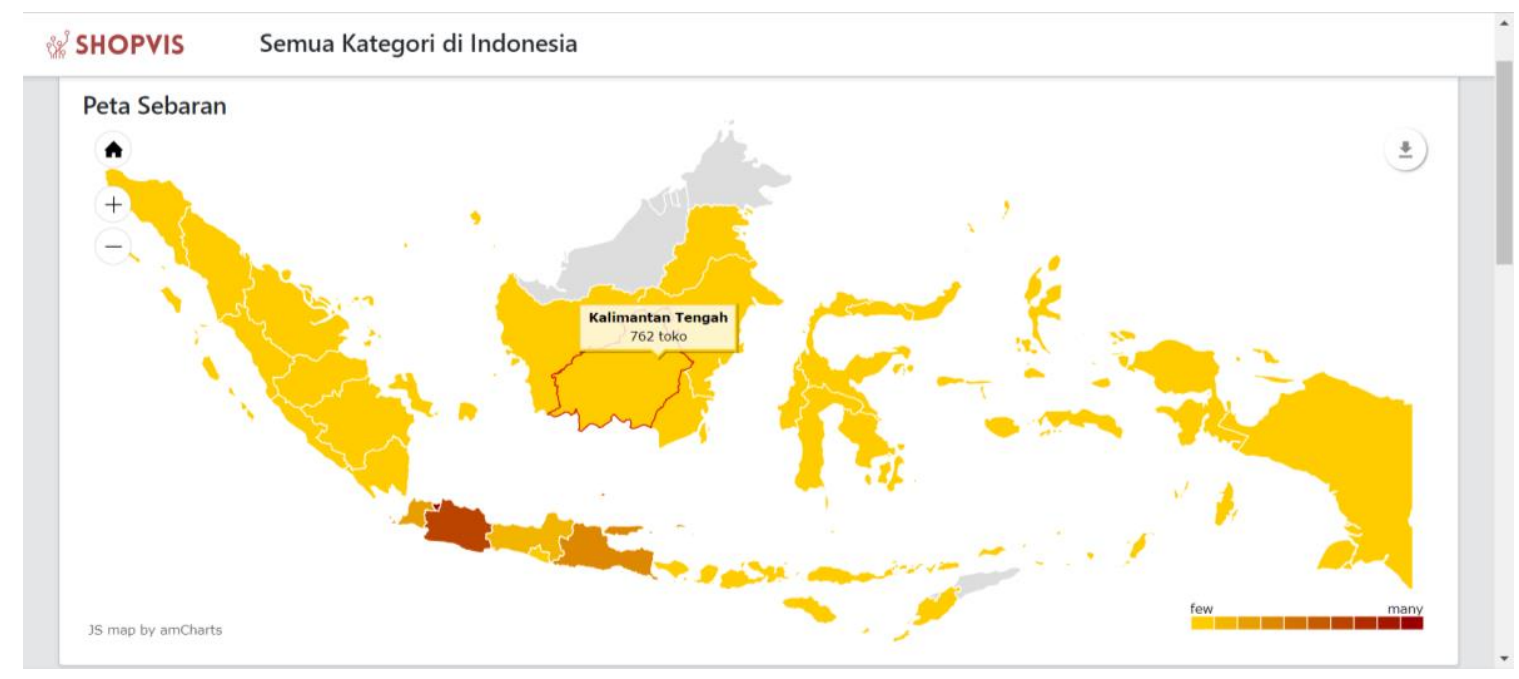

Gambar 7. Visualisasi peta persebaran toko daring di Indonesia

\section{\% SHOPVIS Semua Kategori di Indonesia}

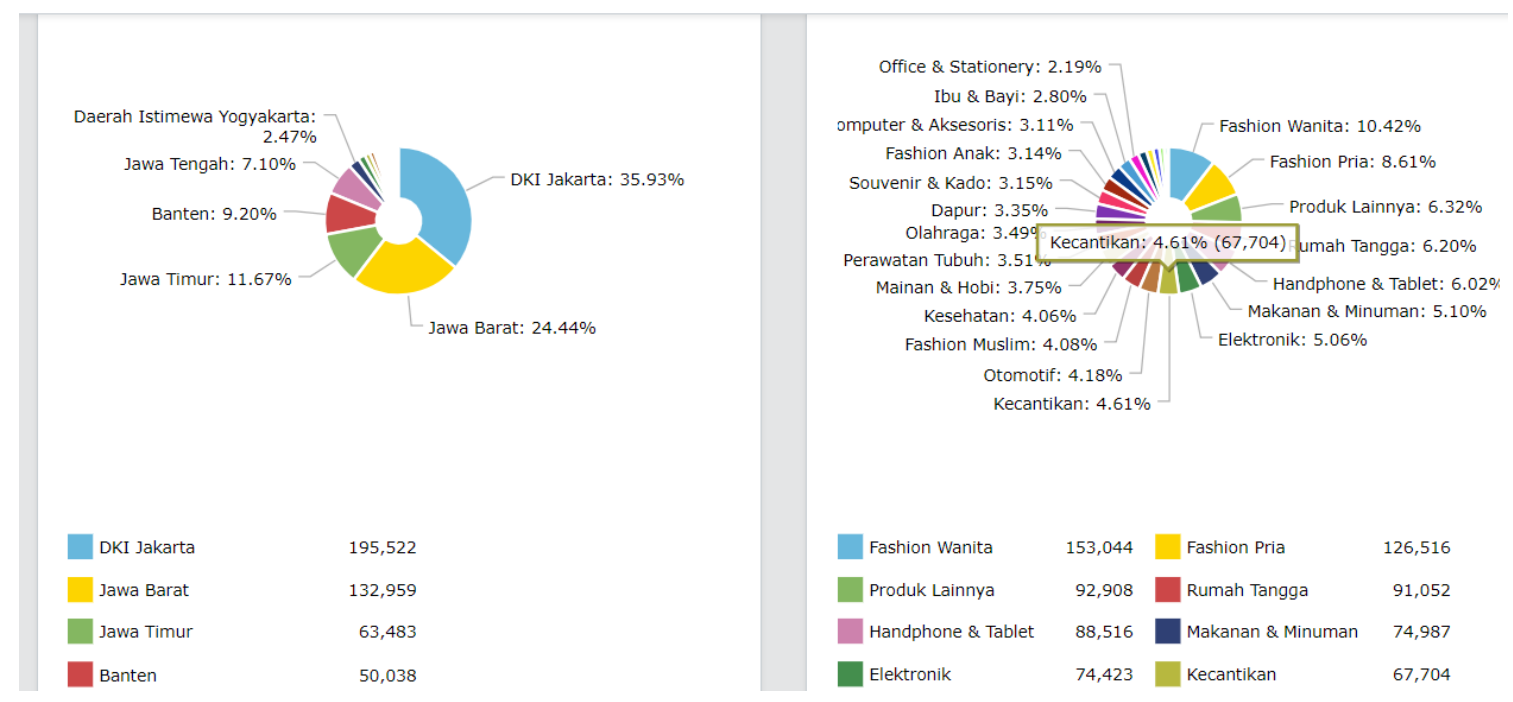

Gambar 8. Visualisasi peta persebaran toko daring berdasarkan daerah dan ketogori

\subsection{Pengujian dan Perbaikan}

Pengujian dilakukan untuk memaksimalkan kinerja ShopVis. Rata-rata waktu akses untuk proses data di ShopVis adalah lebih 5 detik, sebagaimana terlihat pada Gambar 9. Jika dilihat dari komposisi waktu aksesnya, lamanya akses halaman ini didominasi pada proses pengambilan data dari web server yang mencapai $96.4 \%$ (5639.5 ms). Sedangkan akses komponen halaman lain yaitu HTML Document dan Assets (CSS, Javascript) hanya memakan 3.6\% dari total akses waktu.

Untuk mempercepat akses halaman ini, maka dilakukan perubahan pada metode pemrosesan request pengunjung laman visualisasi. Proses awal ditunjukkan pada Gambar 10. Pada saat client melakukan request ke server ShopVis, maka server akan melakukan query ke database, mengolahnya, kemudian 
menampilan hasilnya ke pengguna. Proses query ke database ini dapat memakan waktu yang lama karena banyaknya data yang disimpan dalam database.

Rata-rata durasi akses halaman (ms)

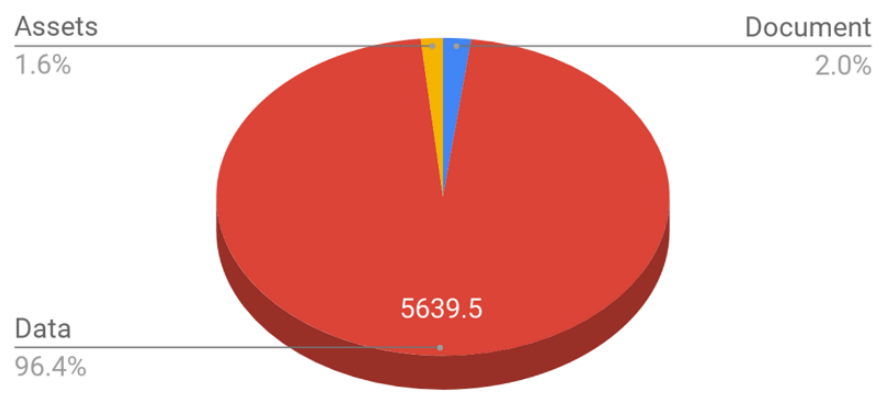

Gambar 9. Rata-rata durasi akses halaman sebelum perbaikan

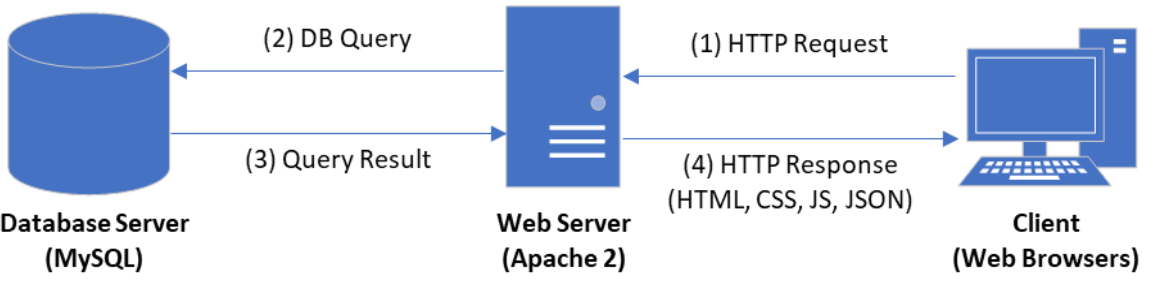

Gambar 10. Alur akses awal

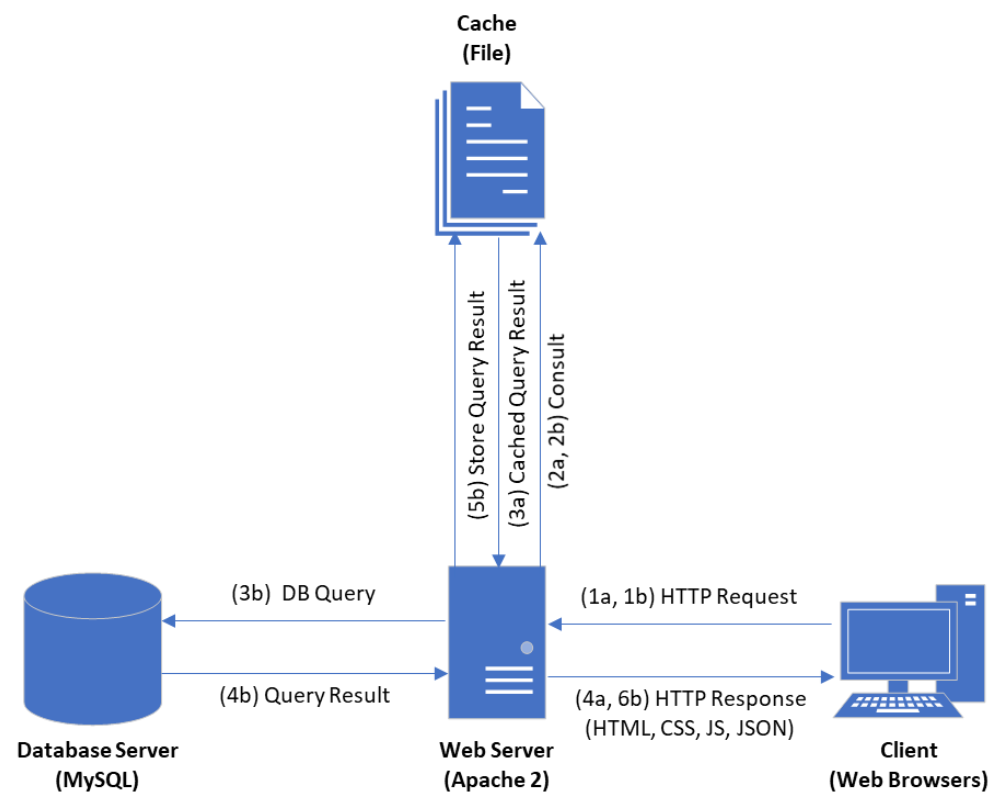

Gambar 11. Alur akses setelah dilakukan perbaikan 
Dengan pertimbangan data yang diakses masing-masing pengunjung adalah data yang sama, maka dilakukan perbaikan pada proses dengan menambahkan mekanisme caching menggunakan file seperti yang ditunjukkan pada Gambar 11.

Setelah dilakukan penambahan cache, server tidak langsung melakukan query ke database ketika menerima request dari client. Server terlebih dahulu memeriksa apakah data yang diminta client telah tersimpan di cache. Jika ada, maka data langsung dikembalikan ke client sehingga dapat mempersingkat waktu pemrosesan. Jika data masih belum tersedia di cache, maka server melakukan query seperti alur awal. Namun, sebelum data dikembalikan ke client, data terlebih dahulu disimpan dalam cache sehingga waktu proses berikutnya akan lebih singkat. Proses perbaikan ini mampu mempercepat waktu akses ratarata menjadi kurang dari 0.3 detik seperti yang ditunjukkan pada Gambar 12.

\section{Rata-rata durasi akses halaman (ms)}

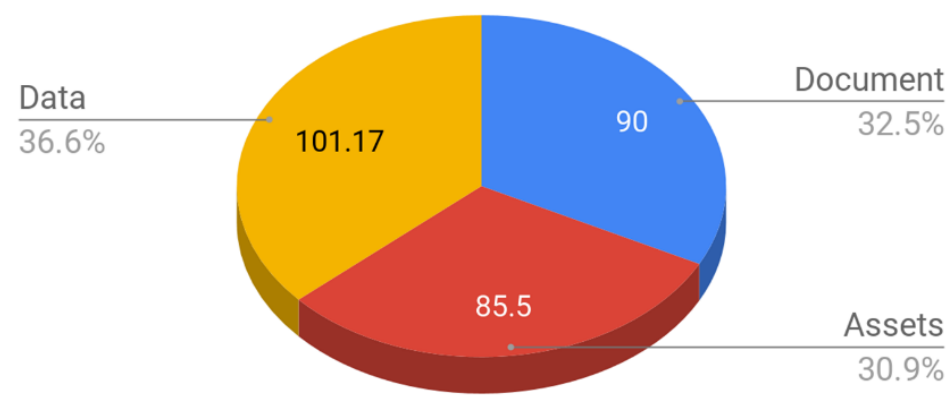

Gambar 12. Rata-rata durasi akses halaman setelah perbaikan

\section{Kesimpulan}

\subsection{Simpulan}

Penelitian ini menghasilkan visualisasi peta persebaran toko daring yang ada di Indonesia berdasarkan daerah dan kategori produk. Pemerintah atau pemegang kepentingan dapat menggunakan visualisasi tersebut untuk memantau kondisi toko daring di masing-masing wilayah di Indonesia meliputi jumlah persebaran toko dan jenis-jenis barang yang dijual. Hasil pengujian menunjukkan bahwa software visualisasi yang telah dibangun berfungsi baik dengan performa yang cukup memuaskan dengan waktu akses rata-rata sebesar kurang dari 0.3 detik untuk masing-masing request.

\subsection{Saran}

Hasil penelitian ini sangat mungkin untuk dilanjutkan untuk riset pasar bisnis, pengelompokan (clustering) daerah-daerah dengan karakteristik yang sama. Penelitian selanjutnya dapat dilakukan dengan menggabungan data dari beberapa pasar daring yang ada di Indonesia.

\section{Daftar Rujukan}

[1] Kementrian Komunikasi dan Informatika, "Kementrian Komunikasi dan Informatika: Potensi Besar untuk Pemasukan Negara," 1211 2015. [Online]. Available: https://kominfo.go.id/index.php/content/detail/6385/P/0/infografis. [Accessed 8 Juni 2017]. 
[2] PT Tokopedia, "Tokopedia," 2017. [Online]. Available: https://www.tokopedia.com/. [Accessed 8 June 2017].

[3] PT Bukalapak.com, "Bukalapak," 2017. [Online]. Available: https://www.bukalapak.com/. [Accessed 8 Juni 2017].

[4] J. W. Tukey, Exploratory Data Analysis, 1st ed., New York: Pearson, 1977.

[5] W. Chauvenet, A Manual of Spherical and Practical Astronomy Vol. II, 5th ed., New York: Dover, 1863.

[6] R. B. Dean and W. J. Dixon, "Simplified Statistics for Small Numbers of Observations," Anal. Chem., vol. 23, no. 4, pp. 636638, 1951.

[7] D. Yates, D. S. Moore and . D. S. Starnes, The Practice of Statistics, 3rd ed., New York: W. H. Freeman, 2008.

[8] M. Grandjean, "Introduction à la visualisation de données, l'analyse de réseau en histoire," Geschichte und Informatik, vol. 18, no. 19 , pp. 109-128, 2015.

[9] V. Friedman, "Data Visualization and Infographics," in Graphics, Monday Inspiration, 2008.

[10] S. Liu, W. Cui, Y. Wu and M. Liu, "A survey on information visualization: recent advances and challenges," The Visual Computer, vol. 30, no. 12, p. 1373-1393, 2014.

[11] U. Brandes and B. Nick, "Asymmetric Relations in Longitudinal Social Networks," IEEE Transactions on Visualization and Computer Graphics, vol. 17, no. 12, pp. 2283-2290, 2011.

[12] S. Afzal, R. Maciejewski, Y. Jang, N. Elmqvist and D. S. Ebert, "Spatial Text Visualization Using Automatic Typographic Maps," IEEE Transactions on Visualization and Computer Graphics, vol. 18, no. 12, pp. 2556-2564, 2012.

[13] A. Slingsby, J. Dykes and J. Wood, "Exploring Uncertainty in Geodemographics with Interactive Graphics," IEEE Transactions on Visualization and Computer Graphics, vol. 17, no. 12, pp. 2545-2554, 2011.

[14] N. Cao, D. Gotz, J. Sun and H. Qu, "DICON: Interactive Visual Analysis of Multidimensional Clusters," IEEE Transactions on Visualization and Computer Graphics, vol. 17, no. 12, pp. 2581-2590, 2011.

[15] M. C. Hao, U. Dayal, M. Hsu, T. Sprenger and M. H. Gross, "Visualization of directed associations in e-commerce transaction data," in Data Visualization 2001: Proceedings of the Joint Eurographics --- IEEE TCVG Symposium on Visualization in Ascona, Switzerland, May 28--30, 2001, D. S. Ebert, J. M. Favre and R. Peikert, Eds., Vienna, Springer Vienna, 2001, pp. 185-192.

[16] B. Bradie, A Friendly Introduction to Numerical Analysis, New York: Pearson Education, 2006.

[17] S. Arlinghaus, Practical Handbook of Curve Fitting, 1st ed., Florida: CRC Press, 1994. 
